\title{
FIRST RECORD OF THE POR'S GOATFISH UPENEUS PORI (ACTINOPTERYGII: PERCIFORMES: MULLIDAE) FROM ITALIAN WATERS (WESTERN IONIAN SEA)
}

\author{
Alan DEIDUN ${ }^{1 *}$, Bruno ZAVA ${ }^{2}$, Gianni INSACCO ${ }^{3}$, and Maria CORSINI-FOKA ${ }^{4}$ \\ ${ }^{1}$ Department of Geosciences, Faculty of Science, University of Malta, Msida, Malta \\ ${ }^{2}$ Wilderness studi ambientali, Palermo, SIC, Italy \\ ${ }^{3}$ Museo Civico di Storia Naturale, Comiso, SIC, Italy \\ ${ }^{4}$ Hellenic Centre for Marine Research, Institute of Oceanography, Hydrobiological Station of Rhodes, \\ Rhodes, Greece
}

Deidun A., Zava B., Insacco G., Corsini-Foka M. 2018. First record of the Por's goatfish Upeneus pori (Actinopterygii: Perciformes: Mullidae) from Italian waters (western Ionian Sea). Acta Ichthyol. Piscat. 48 (1): 93-97.

\begin{abstract}
During May 2017, two specimens of the Lessepsian fish species, Upeneus pori Ben-Tuvia et Golani, 1989, were recorded for the first time from the waters off eastern Sicily, Italy, along the western Ionian Sea. The species apparently expanded its distribution within the central Mediterranean, from the already colonized Tunisian waters. This new finding increases to nine the number of Lessepsian fish species reported from southern Italian waters to date.
\end{abstract}

Keywords: Upeneus pori, Lessepsian migrant, Sicily, Italy, Ionian Sea

Six mullid species have been reported to date from the Mediterranean Sea: the native Mullus barbatus Linnaeus, 1758 and Mullus surmuletus Linnaeus, 1758, the Lessepsian Upeneus moluccensis (Bleeker, 1855), Upeneus pori Ben-Tuvia et Golani, 1989, and Parupeneus forsskali (Fourmanoir et Guézé, 1976) (see Golani et al. 2006, Bariche et al. 2013, Chartosia and Michailidis 2016), and the west African Pseudupeneus prayensis (Cuvier, 1829) (see Azzouz et al. 2011). To date, of these mullid species, only the first two autochthonous species were known from Italian waters (Relini and Lanteri 2010).

The Por's goatfish, Upeneus pori, is a subtropical species, distributed along the western Indian Ocean, from the southern part of the Red Sea to southern Oman (Ben-Tuvia and Golani 1989). This species entered the Mediterranean via the Suez Canal (Golani 2010) where it was first recorded in the Gulf of Iskenderun (Turkey) by Kosswig (1950) as Upenoides (= Upeneus) tragula. Since its initial detection in the Mediterranean, U. pori has been considered to have successfully established itself in the Levantine basin, extending westwards as far as the Aegean Sea and the central Mediterranean (Fig. 1, Table 1).

It is a commercially important demersal species, living mostly on sandy and muddy substrates up to a depth of $50 \mathrm{~m}$, and caught in large quantities through trawling in shallow waters (10-40 m) along the eastern Levantine Sea coasts (Yemisken et al. 2014, Bilecenoğlu 2016).

The first record of $U$. pori in southern Italian waters is hereby reported and the distribution of the species in the Mediterranean Sea is updated. The current occurrence of this fish of Indo-Pacific, Indian, and Red Sea origin in the central Mediterranean is briefly reviewed.

On 2 May 2017, the first specimen of Upeneus pori was caught, by a local fisherman using a traditional seine net (called by Sicilian fishermen "tartarone") in the coastal waters off Catania, on the Italian island of Sicily, within the western Ionian $\left(37.471359^{\circ} \mathrm{N}, 15.086969^{\circ} \mathrm{E}\right)$, from a depth of about $8 \mathrm{~m}$ over a sandy bottom (Fig. 1). The individual was caught jointly with the following species: Mullus barbatus, Lithognathus mormyrus (Linnaeus, 1758), Diplodus annularis (Linnaeus, 1758), and Boops boops (Linnaeus, 1758). The fisherman reported that, during the fishing operations, he was intrigued by the appearance of the captured individual of $U$. pori, since he had never observed such a species before; hence, he photographed the live specimen and released it.

Four days later, on 25 May 2017, a second specimen of the same species was captured in the same area, at a distance of just a few hundred metres away from the first collection site. This specimen was retained. The fresh specimen (Fig. 2) was measured, weighed, photographed, 
and identified according to the characteristics listed for the species by Golani et al. (2006).

Morphometric measures taken for the specimen are presented in Table 2. The meristic data for the same specimen are the following: dorsal fins (D1 + D2) VII + 9; pelvic fin $\mathrm{I}+5$; pectoral fin 13 ; anal fin $\mathrm{I}+7$.

The fresh specimen exhibited the following live colouration: back and sides mottled, brown-reddish. Belly whitish. Upper lobe of caudal fin with a number of reddishbrown bars separated by a white interspace. Lower lobe with a number of bars of the same colour.

The specimen was preserved in formaldehyde solution and is currently archived within the fish collection of the Museo di Storia Naturale di Comiso (Province of Ragusa), with the catalogue number MSNC 4552.
This capture actually documents the first record of Upeneus pori in Italian waters. Its occurrence in the Ionian waters of Sicily may constitute the initial phase of expansion of its distribution from Tunisia, where it is established (Ounifi-Ben Amor et al. 2016). This Lessepsian migrant species is one of the most successful colonizers of the Mediterranean, but, at present, there is scant information concerning its establishment in this new region of the basin - the central Mediterranean.

To date, within Tunisian, Maltese, and Italian waters, a total of thirty-three fish species of Indo-Pacific, Indian Ocean, Red Sea, and Pacific Ocean origin has been recorded. Independently of their vector of introduction to the central Mediterranean, twenty-two non-indigenous fish species of the above-mentioned origin have been recorded to date in Tunisia (Boussellaa et al. 2016, Dailianis et al.

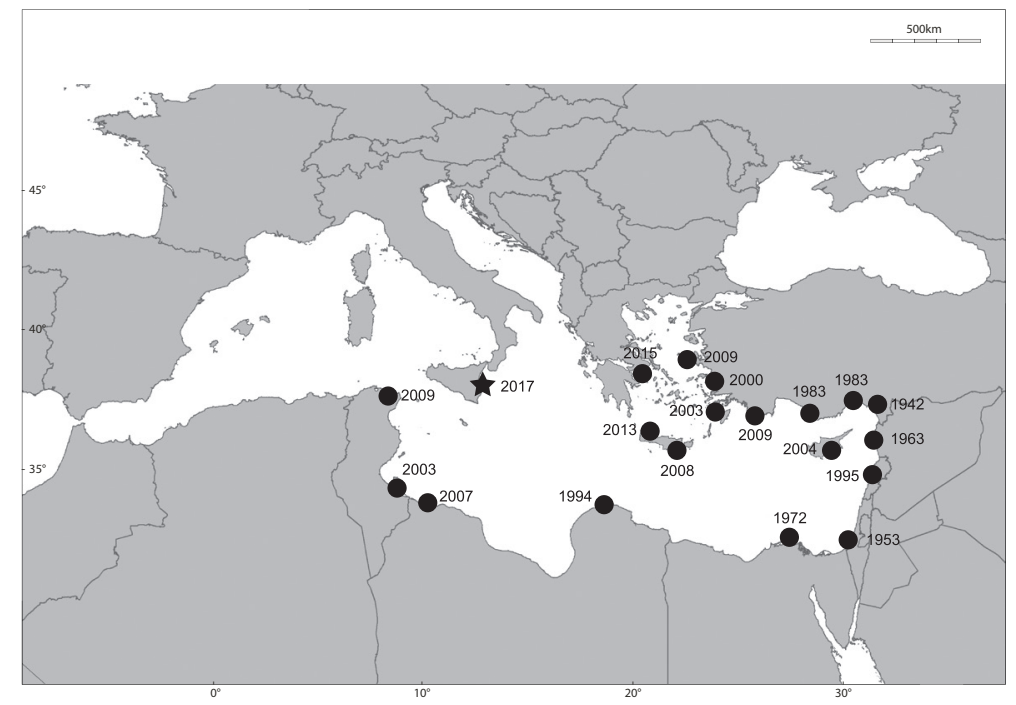

Fig. 1. Records of Upeneus pori in the Mediterranean Sea; circle = literature data; star = presently reported study; details available in Table 1

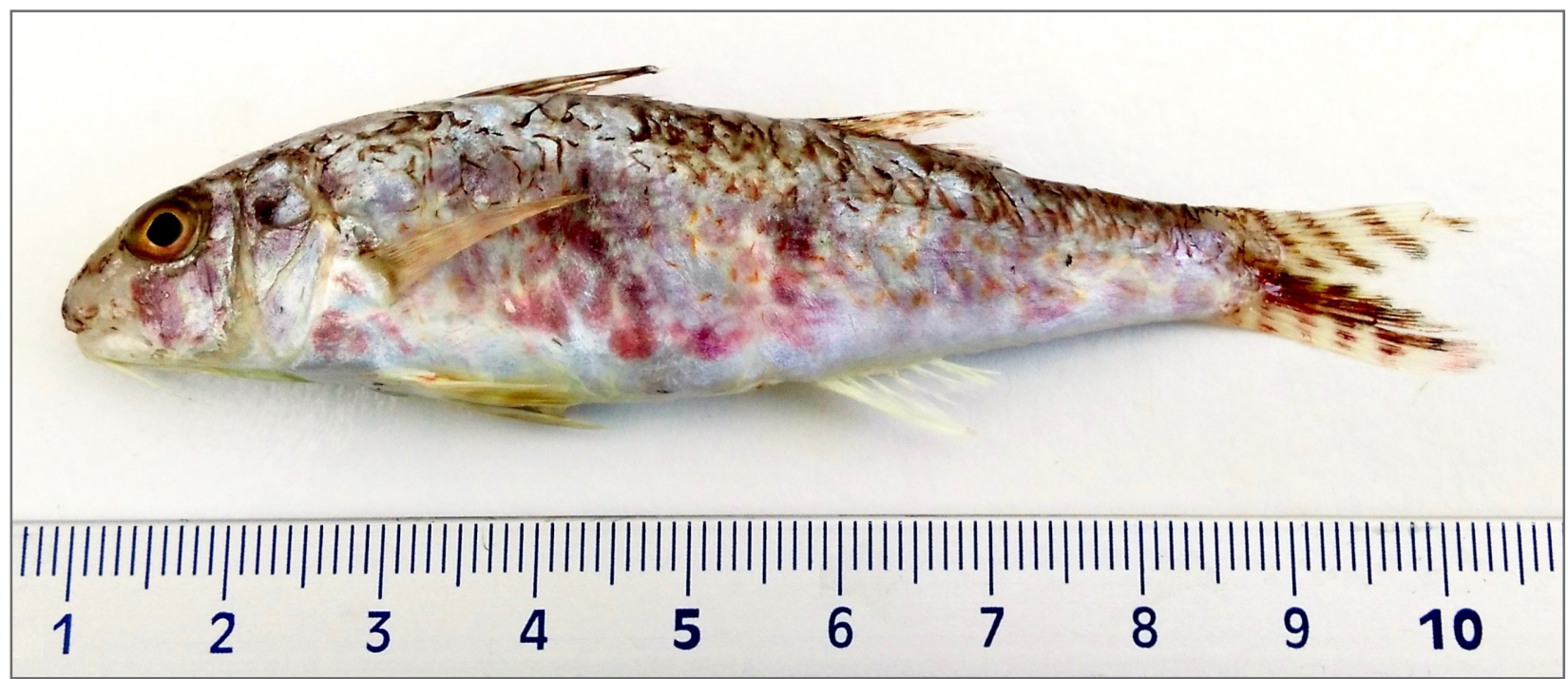

Fig. 2. The second specimen of Upeneus pori, reported in this study and caught off Catania, Ionian Sea, Italy 
Table 1

Records of Upeneus pori in the Mediterranean

\begin{tabular}{lcl}
\hline \multicolumn{1}{c}{ Region } & Year & \multicolumn{1}{c}{ Reference } \\
\hline Turkey (Iskenderun Bay) & 1942 & Kosswig 1950 \\
Israel & 1953 & Ben-Tuvia 1953 \\
Lebanon & 1963 & George and Athanassiou 1966-1967 \\
Syria & 1995 & Saad 2005 \\
Egypt & 1972 & Halim and Rizkalla 2011 \\
Turkey (Iskenderun, Mersin, Incekum-Anamur) & 1983 & Gucu et al. 1994 \\
Libya (eastern coasts) & 1994 & Bazairi et al. 2013 \\
Turkey (Gökova Bay) Aegean Sea & $2000-2001$ & Öğretmen et al. 2005 \\
Greece (Rhodes) Aegean Sea & 2003 & Corsini et al. 2005 \\
Southern Tunisia (Bahiret el Biban Lagoon) & 2003 & Ben Souissi et al. 2005 \\
Cyprus & 2004 & Chartosia and Michailidis 2016 \\
Libya (western coast) & 2007 & El-Drawany 2013 \\
Greece (southern Crete) Libyan Sea & 2008 & Lefkaditou et al. 2010 \\
Turkey (Kuşadasi) Aegean Sea & 2009 & Nikolaidou et al. 2012 \\
Northern Tunisia (Bizerte Lagoon) & 2009 & Azzouz et al. 2010 \\
Greece (Kastellorizo) & 2009 & ELNAIS \\
Greece (northern Crete) Aegean Sea & $2013-2014$ & Skarvelis et al. 2015 \\
Greece (Saronikos Gulf) & 2015 & Karachle et al. 2016 \\
\hline
\end{tabular}

ELNAIS = Ellenic Network on Aquatic Invasive Species. https://elnais.hcmr.gr

2016, Ounifi-Ben Amor et al. 2016), fifteen in Maltese waters (Schembri et al. 2012, Evans et al. 2015, Deidun et al. 2015, Gerovasileiou et al. 2017), and fifteen in Italian waters too, including the presently reported $U$. pori (see Occhipinti-Ambrogi et al. 2011, Azzurro et al. 2014, 2017, Falautano et al. 2014, Karachle et al. 2016, Insacco and Zava 2017). Among the fifteen species recorded in Italy, eleven are considered Eritrean species introduced via the Suez Canal (Lessepsian migrants; Golani 2010), of which nine have already been recorded within the southern Italian waters, off the islands of Sicily and Lampedusa: Etrumeus golanii DiBattista, Randall et Bowen, 2012; Fistularia commersonii Rüppell, 1838; Hemiramphus far (Forsskål, 1775); Lagocephalus sceleratus (Gmelin, 1789); Pterois miles (Bennett, 1828); Siganus luridus (Rüppell, 1829); Siganus rivulatus Forsskål et Niebuhr, 1775; Stephanolepis diaspros Fraser-Brunner, 1940; and the presently reported $U$. pori.

The above nine Lessepsian species reported from Sicily and Lampedusa represent $10 \%$ of the Lessepsian migrant fish species recorded so far in the Mediterranean (102 species up to the end of 2016; Corsini-Foka et al. 2017) and this number is expected to increase, since, as assessed by Golani (2010), “once a Lessepsian migrant has arrived into the Mediterranean and established a sustainable population, there are no significant physical barriers preventing its westward dispersal".

Upeneus pori co-occurs with two other mullid species of great commercial importance in the Mediterranean, especially for the trawling industry-Mullus barbatus and Mullus surmuletus - and thus this finding is interesting since it is a call for a greater monitoring effort of Mediterranean populations of the new arrival. The authors of this study are not in a position to state whether the two
Table 2

Morphometric characteristics [mm] and weight [g] of the specimen of Upeneus pori caught off Catania, Sicily, Italy

\begin{tabular}{lr}
\multicolumn{1}{c}{ Parameter } & Value \\
\hline Total length & 96.8 \\
Length to fork & 84.4 \\
Standard length & 74.2 \\
Head length & 19.6 \\
Snout length & 5.2 \\
Interorbital width & 8.0 \\
Eye diameter & 5.6 \\
Barbels length & 9.9 \\
Caudal fin height & 15.3 \\
Caudal peduncle length & 16.9 \\
Caudal peduncle depth & 8.1 \\
Predorsal length & 26.0 \\
Pectoral fin length & 16.0 \\
Pectoral fin base & 3.0 \\
Second dorsal fin height & 11.6 \\
Second dorsal fin base & 10.2 \\
Pelvic fin length & 14.0 \\
Pelvic fin base & 2.8 \\
Anal fin height & 11.7 \\
Anal fin base & 8.6 \\
Weight & 9.0 \\
\hline
\end{tabular}

$U$. pori records documented in this study actually refer to the same individual or to two different individuals. If the latter is the case, this might signal a more extensive establishment of the species within the collection area than previously thought. 


\section{ACKNOWLEDGEMENTS}

We are grateful to Mr Nenè Napoli for communicating promptly the first finding of Upeneus pori and to Mr Lorenzo Molino from the fishing vessel Marialucia for providing us with the second specimen.

\section{REFERENCES}

Azzouz K., Diatta Y., Mansour S., Boumaïza M., Ben Amor M.M., Capapé C. 2011. First record of the west African goatfish, Pseudupeneus prayensis (Actinopterygii: Perciformes: Mullidae), off the Tunisian coast (central Mediterranean). Acta Ichthyologica et Piscatoria 41 (2): 133-136. DOI: 10.3750/AIP2011.41.2.10

Azzouz K., Mansour S., Boumaïza M., Capapé C. 2010. Occurrence of the Por's goatfish Upeneus pori (Osteichthyes: Mullidae) in the Lagoon of Bizerte (northern Tunisia, central Mediterranean). Annales, Series Historia Naturalis 2 (1): 29-32.

Azzurro E., Castriota L., Falautano M., Giardina F., Andaloro F. 2014. The silver-cheeked toadfish Lagocephalus sceleratus (Gmelin, 1789) reaches Italian waters. Journal of Applied Ichthyology 30 (5): 1050-1052. DOI: 10.1111/jai.12471

Azzurro E., Stancanelli B., Di Martino V., Bariche M. 2017. Range expansion of the common lionfish Pterois miles (Bennett, 1828) in the Mediterranean Sea: An unwanted new guest for Italian waters. BioInvasions Records 6 (2): 95-98. DOI: 10.3391/ bir.2017.6.2.01

Bariche M., Bilecenoglu M., Azzurro E. 2013. Confirmed presence of the Red Sea goatfish Parupeneus forsskali (Fourmanoir \& Guézé, 1976) in the Mediterranean Sea. BioInvasions Records 2 (2): 173-175. DOI: 10.3391/ bir.2013.2.2.15

Bazairi H., Sghaier Y.R., Benamer I., Langar H., Pergent G., Bourass E.M.,Verlaque M., Ben Soussi J., Zenetos A. 2013. Alien marine species of Libya: First inventory and new records in El-Kouf National Park (Cyrenaica) and the neighbouring areas. Mediterranean Marine Science 14 (2): 451-462. DOI: $10.12681 / \mathrm{mms} .555$

Ben Souissi J., Mejri H., Zauali J., Capapé C. 2005. On the occurrence of the Por's goatfish, Upeneus pori (Mullidae) in southern Tunisia (central Mediterranean). Cybium 29 (4): 410-412.

Ben-Tuvia A. 1953. Mediterranean fishes of Israel. State of Israel, Ministry of Agriculture, Department of Fisheries, Sea Fisheries Research Station, Bulletin No. 8.

Ben-Tuvia A., Golani D. 1989. A new species of goatfish (Mullidae) of the genus Upeneus from the Red Sea and the eastern Mediterranean. Israel Journal of Zoology 36 (2): 103-112.

Bilecenoğlu M. 2016. Demersal Lessepsian fish assemblage structure in the northern Levant and Aegean seas. Journal of the Black Sea/Mediterranean Environment 22 (1): 46-59.

Boussellaa W., Boudaya L., Derbel H., Neifar L. 2016. A new record of the Lessepsian fish Etrumeus golanii
(Teleostei: Clupeidae) in the Gulf of Gabes, Tunisia, with notes on its parasites. Cahiers de Biologie Marine 57: 389-395.

Chartosia N., Michailidis N. 2016. First confirmed presence of the Red Sea goatfish Parupeneus forsskali (Fourmanoir \& Guézé, 1976) from Cyprus. Marine Biodiversity Records 9: e33. DOI: 10.1186/s41200016-0032-7

Corsini M., Margies P., Kondilatos G., Economidis P.S. 2005. Lessepsian migration of fishes to the Aegean Sea: First record of Tylerius spinosissimus (Tetraodontidae) from the Mediterranean, and six more fish records from Rhodes. Cybium 29 (4): 347-354.

Corsini-Foka M., Mastis S., Kondylatos G., Batjakas I.E. 2017. Alien and native fish in gill nets at Rhodes, eastern Mediterranean (2014-2015). Journal of the Marine Biological Association of the United Kingdom 97 (3): 635-642. DOI: 10.1017/S0025315417000467

Dailianis T., Akyol O., Babali N., Bariche M., Crocetta F., Gerovasileiou V., Chanem R., Gökoğlu M., Hasiotis T., Izquierdo-Muñoz A., Julian D., Katsanevakis S., Lipez L., Mancini E., Mytilineou C., Ounifi Ben Amor K., Özgül A., Ragkousis M., Rubio-Portillo E., Servello G., Sini K., Stamouli C., Sterioti A., Teker S., Tiralongo F., Trkov D. 2016. New Mediterranean biodiversity records (July 2016). Mediterranean Marine Science 17 (2): 608-626. DOI: $10.12681 / \mathrm{mms} .1734$

Deidun A., Fenech-Farrugia A., Castriota L., Falautano M., Azzurro E., Andaloro F. 2015. First record of the silver-cheeked toadfish Lagocephalus sceleratus (Gmelin, 1789) from Malta. BioInvasions Records 4 (2): 139-142. DOI: 10.3391/bir.2015.4.2.11

El-Drawany M.A. 2013. Some biological aspects of the Por's goatfish, (Family: Mullidae) from Tripoli coast of Libya. Egyptian Journal of Aquatic Research 39 (4): 261-266. DOI: 10.1016/j.ejar.2013.11.003

Evans J., Barbara J., Schembri P.J. 2015. Updated review of marine alien species and other 'newcomers' recorded from the Maltese Islands (central Mediterranean). Mediterranean Marine Science 16 (1): 225-244. DOI: 10.12681/mms.1064

Falautano M., Castriota L., Battaglia P., Romeo T., Andaloro F. 2014. First record of the Lessepsian species Hemiramphus far (Hemiramphidae) in Italian waters. Cybium 38 (3): 235-237.

Gerovasileiou V., Akel E.H.K., Akyol O., Alongi G., Azevedo F., Babali N., Bakiu R., Bariche M., Bennoui A., Castriota L., Chintiroglou C.C., Crocetta F., Deidun A., Galinou-Mitsoudi S., Giovos I., Gökoğlu M., Golemaj A., Hadjioannou L., Hartingerova J., Insacco G., Katsanevakis S., Kleitou P., Korun J., Lipej L., Malegue M., Michailidis N., Mouzai Tifoura A., Ovalis P., Petović S., Piraino S., Rizkalla S.I., Rousou M., Savva I., Şen H., Spinelli A., Vougioukalou K.G., Xharahi E., Zava B., Zenetos A. 2017. New Mediterranean biodiversity records (July 2017). Mediterranean Marine Science 18 (2): 355-384. DOI: $10.12681 / \mathrm{mms} .13771$ 
George C.J., Athanassiou V.A. 1966-1967. Observations on Upeneus asymmetricus Lachner, 1954 in St. George bay, Lebanon. Annali del Museo civico di storia naturale "Giacomo Doria" 76: 68-74.

Golani D. 2010. Colonization of the Mediterranean by Red Sea fishes via the Suez Canal-Lessepsian migration. Pp. 145-188. In: Golani D., AppelbaumGolani B. (eds.) Fish invasions of the Mediterranean Sea: Change and renewal. Pensoft Publishers, Sofia, Bulgaria and Moscow, Russia.

Golani D., Öztürk B., Başusta N. 2006. Fishes of the eastern Mediterranean. Turkish Marine Research Foundation, Istanbul, Turkey.

Gucu A., Bingel C., Avasar D., Uysal N. 1994. Distribution and occurrence of Red Sea fishes at the Turkish Mediterranean coast-northern Cilician basin. Acta Adriatica 34 (1-2): 103-113.

Halim Y., Rizkalla S. 2011. Aliens in Egyptian Mediterranean waters. A check-list of Erythrean fish with new records. Mediterranean Marine Science 12 (2): 479-490. DOI: 10.12681/mms.46

Insacco G., Zava B. 2017. Chlorurus rhakoura Randall \& Anderson, 1997 (Perciformes, Scaridae), an Indo-Pacific fish new for the Mediterranean Sea. Mediterranean Marine Science 18 (2): 285-291.

Karachle P.K., Angelidis A., Apostolopoulos G., Ayas D., Ballesteros M., Bonnici C., M. Brodersen M., Castriota L., Chalari N., Cottalorda J.M., Crocetta F., Deidun A., Đođo Ž., Dogrammatzi A., Dulčić J., Fiorentino F., Gönülal O., Harmelin J.G., Insacco G., Izquierdo-Gómez D., Izquierdo-Muñoz A., Joksimović A., Kavadas S., Malaquias M.A.E., Madrenas E., Massi D., Micarelli P., Minchin D., Önal U., Ovalis P., Poursanidis D., Siapatis A., Sperone E., Spinelli A., Stamouli C., Tiralongo F., Tunçer S., Yaglioglu D., Zava B., Zenetos A. 2016. New Mediterranean biodiversity records (March 2016). Mediterranean Marine Science 17 (1): 230252. DOI: $10.12681 / \mathrm{mms} .1684$

Kosswig C. 1950. Erythräische Fische im Mittelmeer und an der Grenze der Ägais. Pp. 203-212. In: Von Jordans A., Peus F. (eds.) Syllegomena Biologica. Festschrift zum 80. Geburtstage von Herrn Pastor Dr. Med. H.C. Otto Kleinschmidt, Lutherstadt Wittenberg am 13. Dezember 1950. Geest und Portig K.-G./A. Ziemsen Verlag, Leipzig und Wittenberg, Germany.

Lefkaditou E., Vassilopoulou V., Petrakis G., Peristeraki P., Kavadas S., Politou C.-Y., Kapantagakis A., Machias A., Papaconstantinou C. 2010. The effect of Lessepsian immigrants to the Hellenic fisheries. Pp. 60-73. In: Report of the technical meeting on the Lessepsian migration and its impact on eastern
Mediterranean fishery. 7-9 December 2010, Nicosia, Cyprus. EastMed Technical Documents 04. GCP/ INT/041/EC-GRE-ITA/TD-04.

Nicolaidou A., Alongi G., Aydogan O., Catra M., Cavas L., Cevik C., Dosi A., Circosta V., Giakoumi S., Gimenez-Casalduero F., Filiz H., Izquierdo-Munoz A., Kalogirou S., Konstantinidis E., Kousteni V., Kout J., Legaki A., Megalofonou P., Ovalis P., Paolillo G., Paschos I., Perdikaris C., Poursanidis D., Ramos-Espla A.A., Reizopoulou S., Sperone E., Taskin E., Tripepi S., Vazquez-Luis M. 2012. New Mediterranean biodiversity records (June 2012). Mediterranean Marine Science 13 (1): 162-174. DOI: $10.12681 / \mathrm{mms} .33$

Occhipinti-Ambrogi A., Marchini A., Cantone G., Castelli A., Chimenz C., Cormaci M., Froglia C., Furnari G., Gambi M.C., Giaccone G., Giangrande A., Gravili C., Mastrototaro F., Mazziotti C., OrsiRelini L., Piraino S. 2011. Alien species along the Italian coasts: An overview. Biological Invasions 13 (1): 215-237. DOI: 10.1007/s10530-010-9803-y

Ounifi-Ben Amor K., Rifi M., Ghanem R., Draeif I., Zaouali J., Ben Souissi J. 2016. Update of alien fauna and new records from Tunisian marine waters. Mediterranean Marine Science 17 (1): 124-143. DOI: $10.12681 / \mathrm{mms} .1371$

Öğretmen F., Yilmaz F., Torcu Koç H. 2005. An investigation of fishes of Gökova Bay (southern Aegean Sea). Balıkesir Üniversitesi Fen Bilimleri Enstitüsü Dergisi 7 (2): 19-36.

Relini G., Lanteri L. 2010. Osteichthyes. Biologia Marina Mediterranea 17 (Suppl. 1): 649-674.

Saad A. 2005. Check-list of bony fish collected from the coast of Syria. Turkish Journal of Fisheries and Aquatic Sciences 5 (2): 99-106.

Schembri P.J., Deidun A., Falzon M.A. 2012. One Siganus or two? On the occurrence of Siganus luridus and Siganus rivulatus in the Maltese Islands. Marine Biodiversity Records 5: e71. DOI: 10.1017/ S175526721200053X

Skarvelis K., Giannakaki A., Kosoglou G., Peristeraki P. 2015. Data on frequency of occurrence of alien species caught on the coastal fisheries of Crete. Pp. 609-612. In: Proceedings of the 11th Panhellenic Symposium of Oceanography and Fisheries, May 2015, Mytilini, Lesvos, Greece.

Yemisken E., Dalyan C., Eryilmaz L. 2014. Catch and discard fish species of trawl fisheries in the Iskenderun Bay (north-eastern Mediterranean) with emphasis on Lessepsian and chondricthyan species. Mediterranean Marine Science 15 (2): 380-389. DOI: 10.12681/ mms.538 